\title{
PENDIDIKAN KARAKTER DI MADRASAH IBTIDAIYAH
}

\author{
Patimah M.Ag* \\ *Dosen Jurusan PGMI FITK IAIN Syekh Nurjati Cirebon \\ Email:Patimah@yahoo.co.id
}

\begin{abstract}
ABSTRAK
Jenjang pendidikan dasar merupakan fondasi awal untuk melangkah melanjutkan pendidikan. Bila penanaman karakter gagal dilakukan pada tahap usia pendidikan dasar, maka bisa dipastikan, karakter yang tertanam pada peserta didik kurang optimal. Pengembangan pendidikan berkaraktek bagi peserta didik harus diterapkan sungguh-sungguh karena kepribadian dan karakter yang kuat mempengaruhi masa depan bangsa. Anak usia madrasah ibtidaiyah merupakan masa kritis dalam pembentukan karakter. Menurut Freud, kegagalan dalam memberikan penanaman dan pembinaan kepribadian berkarakter pada anak usia madrasah ibtidaiyah akan membentuk pribadi yang bermasalah pada saat dewasa.

Pemerintah melalui Kementerian Pendidikan Nasional mencanangkan pendidikan berbasis karakter untuk semua tingkat pendidikan. Menurut Mendiknas, Prof. Muhammad Nuh, pembentukan karakter perlu dilakukan sejak usia dini. Jika karakter sudah terbentuk sejak usia dini, maka tidak akan mudah untuk mengubah karakter seseorang. Ia juga berharap, pendidikan karakter dapat membangun kepribadian bangsa.
\end{abstract}

Kata Kunci : Pendidikan Karakter, pendidikan Dasar

\section{A. PENDAHULUAN}

Pendidikan saat ini masih diyakini memiliki nilai strategis dan urgen dalam pembentukan karakter suatu bangsa, terutama berkaitan dengan tugas utamanya yakni pembentukan karakter peserta didik. Karenanya mengawal dan merekonstruksi kualitas pendidikan secara berkelanjutan adalah sebuah keniscayaan, sebab pada dasarnya pendidikan secara umum memiliki tugas suci dan mulia, yaitu memberdayakan manusia agar mampu mengaktualisasikan dirinyasecara penuh dalam kehidupan .selain itu pendidikan juga memegang tugas yang tidak kalah penting yaitu mentransformasikan individu- individu menjadi sosok yang berkepribadian baik.

Realitas pendidikan di Indonesia saat ini, Nampak jauh berbeda (bertolak belakang) antara sisi idealitas dengan sisi realitas. Dimana realitas dalam 
konstalasi pendidikan Indonesia saat ini sedang dalam kondisi yang masih dalam kategori stagnan. Mansur ${ }^{1}$ dalam bukunya: Pendidikan Karakter : Menjawab Tantangan Krisis Multidimensional, mengemukakan berbagai fakta ketertinggalan dan kegagalan yang tersaji secara akurat dan mengejutkan. Betapa tidak, berdasarkan hasil Survei PERC (Political and Economic Risk Consultancy) dan UNDP (United Nation Develoment Program ) sebagaimana di kutip dalam buku tersebut menyatakan:

PERC menyebutkan bahwa system pendidikan di Indonesia menempati posisi terburuk di kawasan Asia (dari 12 negara yang di survei oleh PERC). Sementara itu, UNDIP tahun 2004 dan 2005 menyatakan bahwa Indeks Pembangunan Manusia (IPM) di Indonesia pun tetap terpuruk. Tahun 2004 Indonesia menempati urutan 111 dari 175negara: "sedangkan tahun 2005 IPM Indonesia berada pada urutan ke 110 dari 117 Negara". 2

Kesimpulan dan pernyataan yang dilakukan PERC dan UNDIP tentu bukan tanpa alasan. Iwan Gunawan salah seorang Pendidik SDI Al-Farisi Bandung seperti di kutip Mansur Muchlis ${ }^{3}$ mengemukakan perilaku para peserta didik yang begitu jauh dari dimensi karakter. Ia menyebutkan bahwa kekerasan telah terjadi di lembaga-lembaga pendidikan, entah itu dilakukan oleh peserta didik itu sendiri ataupun pendidiknya. Tidak hanya itu, perilaku destruktif lainya seperti peserta didik yang sering memalak temannya, mengucilkan teman dan memusuhinya, mengejek dan menghina teman, mengancam teman yang tidak memberikan contekan, mengambil barang teman dengan paksa, melukai teman secara fisik, mempermalukan teman dan masih banyak lagi. Beberapa tindakan seperti inilah yang kemudian ia sebut dengan bullying (kekerasan) di sekolah.

\footnotetext{
${ }^{1}$ Muslich (Mansur, Muclis. Pendidikan Karakter: Menjawab Tantangan Krisis Multidimensional. Jakarta: Bumi Aksara 2011)

2 (Mansur, Muclis. Pendidikan Karakter: Menjawab Tantangan Krisis Multidimensional. Jakarta: Bumi Aksara 2011)

${ }^{3}$ (Mansur, Muclis. Pendidikan Karakter: Menjawab Tantangan Krisis Multidimensional. Jakarta: Bumi Aksara 2011)
} 
Sementara Abudin $\mathrm{Nata}^{4}$ dalam menyikapi hal ini menyatakan bahwa kejujuran, kebenaran, keadilan, tolong menolong, dan kasih sayang yang sudah tertutup oleh penyelewengan, penipuan, penindasan, saling menjegal, dan saling merugikan. Apa yang menjadi nilai-nilai karakter, seperti sudah hilang ditelan segala keburukan tersebut.

Dengan demikian, menjadi jelas bahwa beberapa realitas buruk yang terjadi dalam dunia pendidikan kita dewasa ini telah banyak meresahkan berbagai kalangan. Seringkali terjadi banyak keluhan dan keritikan pedas dari para orang tua, ahli didik, maupun pihak-pihak terkait lainnya yang merasa gerah dengan segala kemrosotan karakter dalam pendidikan di Indonesia

Untuk itulah, pemerintah menyadari perlunya pembentukan karakter mulai usia dini. Namun, pendidikan karakter yang paling tepat diterapkan secara menyeluruh ada pada usia jenjang pendidikan dasar, dimana usia jenjang pendidikan dasar merupakan usia emas dalam pembentukan karakter, watak, dan kepribadian seseorang. Cliffon Fadiman menyatakan bahwa sekolah/ madrasah kini masih merupakan peta utama atau sebagai satu-satunya peta untuk pulau harta karun yang merasuk pada pikiran peserta didik. ${ }^{5}$

Jenjang pendidikan dasar merupakan fondasi awal untuk melangkah melanjutkan pendidikan. Bila penanaman karakter gagal dilakukan pada tahap usia pendidikan dasar, maka bisa dipastikan, karakter yang tertanam pada peserta didik kurang optimal. Pengembangan pendidikan berkaraktek bagi peserta didik harus diterapkan sungguh-sungguh karena kepribadian dan karakter yang kuat mempengaruhi masa depan bangsa. Anak usia madrasah ibtidaiyah merupakan masa kritis dalam pembentukan karakter. Menurut Freud, kegagalan dalam memberikan penanaman dan pembinaan kepribadian berkarakter pada anak usia madrasah ibtidaiyah akan membentuk pribadi yang bermasalah pada saat dewasa.

Pemerintah melalui Kementerian Pendidikan Nasional mencanangkan pendidikan berbasis karakter untuk semua tingkat pendidikan. Menurut

\footnotetext{
${ }^{4}$ Nata, Abudin. Manajemen Pendidikan :Mengatasi Kelemahan Pendidikan Islam di Indonesia. Jakarta: Prenada Media 2003: 198

${ }^{5}$ Battle\&Robert L. Shannon, Gagasan Baru dalam Pendidikan, Terj. Sams S. Hutabarat, Jakarta: Mutiara, 1978, hlm.33
} 
Mendiknas, Prof. Muhammad Nuh, pembentukan karakter perlu dilakukan sejak usia dini. Jika karakter sudah terbentuk sejak usia dini, maka tidak akan mudah untuk mengubah karakter seseorang. Ia juga berharap, pendidikan karakter dapat membangun kepribadian bangsa.

Merujuk pada pasal 1 ayat 1 Undang-undang No. 20 Tahun 2003 tentang Sistem Pendidikan Nasional (UUSPN) menyatakan bahwa "pendidikan merupakan usaha sadar dan terencana untuk mewujudkan suasana belajar dan proses pembelajaran agar peserta didik secara aktif mengembangkan potensi dirinya untuk memiliki kekuatan spiritual keagamaan, pengendalian diri, kepribadian, kecerdasan, akhlak mulia, serta keterampilan yang diperlukan dirinya, masyarakat, bangsa dan negara".

Hal ini jelas tertuang dalam tujuan pendidikan nasional pasal 3 UU No. 20 tahun 2003 tentang system pendidikan nasional- adalah bertujuan untuk berkembangnya potensi peserta didik agar menjadi manusia yang beriman dan bertaqwa kepada Tuhan Yang Maha Esa, berakhlak mulia, sehat, berilmu, cakap, kreatif, mandiri dan menjadi warga Negara yang demokratis secara bertanggung jawab.

Abdul latif menyatakan bahwa tujuan pendidikan yang telah dirumuskan berdasarkan landasan pancasila dan UUD 1945 pada dasarnya adalah manusia seutuhnya. ${ }^{6}$ Manusia seutuhnya yang dimaksudkan disini adalah pertama, manusia yang beriman dan bertaqwa kepada tuhan yang maha esa. Kedua, berbudi pekerti luhur. Ketiga, memiliki pengetahuan dan ketrampilan. Keempat, sehat jasmani dan rohani. Kelima, berkepribadiaan mantap dan mandiri. Keenam, memiliki rasa tanggung jawab kemasyarakatan dan kebangsaan.

Pemerintah melalui Kementrian Pendidikan Nasional sejak 2 Mei 2010 telah menggulirkan sebuah "terobosan baru" menyangkut keharusan dalam mengembangkan pendidikan berbasis karakter. Pendidikan karakter yang dimaksud sekurang-kurangnya merujuk kepada, adanya keseimbangan antara

\footnotetext{
${ }^{6}$ Abdul latif Pendidikan Berbasis Nilai Kemasyarakatan, Bandung, Refika Aditama, 2007, Hlm 13
} 
moral Knowing(pengetahuan tentang moral), moral feeling(perasaan tentang moral), moral action(perbuatan moral).

Dengan demikian, apa yang kemudian dicita-citakan dalam tujuan UU Sisdiknas No 20 Tahun 2003 sejatinya dapat tercapai dan sinergis dengan apa yang tertuang dalam pola pengembangan pendidikan berbasis karakter. Dalam sosio-historis lembaga pendidikan di Indonesia, jauh sebelum lahirnya lembagalembaga pendidikan maupun model sekolah ataupun madrasah.

\section{B. Hakekat Pendidikan Karakter}

Dalam kamus psikologi dinyatakan bahwa karakter adalah kepribadian ditinjau dari titik tolak etis dan moral, misalnya kejujuran seseorang, biasanya mempunyai sifat-sifat yang relatif tepat. ${ }^{7}$ Menurut The Random House Dictionary of the English Language, Character (karakter) adalah "the aggregate of features and traits from the individual nature of some persons or things" ${ }^{\prime 8}$ (keseluruhan ciri khas yang membentuk watak sekelompok orang atau barang). Menurut Suyanto, karakter adalah cara berpikir dan berprilaku yang menjadi ciri khas tiap individu untuk hidup dan bekerjasama, baik dalam lingkup keluarga, masyarakat, bangsa dan negara. ${ }^{9}$ Individu yang berkarakter baik adalah individu yang dapat membuat keputusan dan siap mempertanggungjawabkan tiap akibat dari keputusan yang ia buat.

Dalam buku yang ditulis Doni Koesoema A., dijelaskan bahwa karakter dapat dilihat dari dua hal, yaitu pertama, sebagai sekumpulan kondisi yang telah diberikan begitu saja, atau telah ada begitu saja, yang lebih kurang dipaksakan dalam diri kita. Karakter demikian ini dianggap suatu yang telah ada (given). Kedua, karakter juga dapat dipahami sebagai tingkat kekuatan melalui mana seorang individu mampu menguasai kondisi tersebut. Karakter yang demikian disebut sebagai proses yang dikehendaki (willed). ${ }^{10}$ ( Doni Koesoema A.,

\footnotetext{
${ }^{7}$ Hamka Abdul Aziz, Pendidikan Karakter Berpusat Pada Hati, (Jakarta: Al-Mawardi Prima, 2011), hal. 197-198

${ }^{8}$ The Random House Dictionary of the English Language, (New York: Random House, Inc 1983), hal. 346

${ }^{9}$ Suyanto, "Urgensi Pendidikan Karakter"(makalah), Dikjen mendikdasmen..... hal. 1

${ }^{10}$ Doni Koesoema A., "pendidikan Karakter”, (strategi mendidik anak dijaman globaL, Jakarta, Grafindo, 2010 hal. 90-91)
} 
“pendidikan Karakter”,(strategi mendidik anak dijaman globaL, Jakarta, Grafindo, 2010 hal. 90-91)

Dari beberapa pengertian diatas dapat ditarik benang merah bahwa hakikat karakter itu adalah sifat utama (pola), baik pikiran, sikap, prilaku maupun tindakan, dan sifat utama (pola) tersebut melekat kuat pada diri seseorang dal menyatu dalam diri seseorang, seperti halnya ukiran yang sulit diubah. ${ }^{111}$ Maragustam Siregar, "Menjadi Manusia Berkarakter...., hal.2

Dalam lingkup pendidikan karakter, keseluruhan aspek kecerdasan (IQ, EQ, SQ dan AQ) perlu mendapat bobot perhatian yang seimbang. Hal ini penting mengingat IQ saja belum menjamin keberhasilan hidup seseorang, bila hanya sekedar SQ dan EQ tidak akan mampu mendukung keberhasilan hidup seseorang secara utuh, materi dan spriritual dengan kepribadian atau karakter yang dimiliki. Selain hal tersebut perlu adanya AQ atau kecerdasan dalam bersikap menghadapi kesulitan atau hambatan. Manurut Paul G. Stolz, ${ }^{12}$, AQ didefinisikan sebagai kemampuan bertahan dalam berbagai kesulitan hidup dan tantangan yang dialami. Contoh orang dengan AQ tinggi, akan menganggap konflik dengna orang yang disayanginya adalah kesalah pahaman bukan hancurnya hubungan; dan kesulitan bukanlah ancaman.

Indikator-indikator kecerdasan adversitas $\mathrm{AQ}$ (Adversity Intelligence) dapat dikelompokan menjadi empat dimensi, yakni: (1) dimensi kendali, (2) dimensi asal usul dan pengakuan, (3) dimensi jangkauan serta (4) dimensi daya tahan.

Tujuan pendidikan karakter menurut Dharma Kesuma dkk., adalah memfasilitasi penguatan dan pengembangan nilai-nilai tertentu sehingga terwujud dalam perilaku anak, baik ketika proses pendidikan maupun setelah proses pendidikan. Penguatan dan pengembangan memiliki makna bahwa pendidikan bukanlah sekedar suatu dogmatisasi nilai kepada peserta didik, tetapi sebuah proses yang membawa peserta didik untuk memahami dan merefleksikan bagaimana suatu nilai menjadi penting untuk diwujudkan dalam perilaku

\footnotetext{
${ }^{11}$ Maragustam Siregar, "Menjadi Manusia Berkarakter...., hal.2

${ }^{12}$ Paul G stolz,’Adversity Quotient, 2000
} 
keseharian peserta didik. Penguatan juga mengarahkan proses pendidikan pada proses pembiasaan yang disertai oleh logika dan refleksi.

Tujuan pendidikan karakter yang selanjutnya adalah mengoreksi perilaku peserta didik yang tidak bersesuaian dengna nilai-nilai yang ada dalam kehidupan keseharian peserta didik. Kemudian didukung dengan membangun hubungan harmonis dengna keluarga dan masyarakat dalam memerankan tanggung jawab pendidikan karakter secara bersama. ${ }^{13}$

Dalam mencapai tujuan tersebut, diperlukan upaya-upaya serius dan berkelanjutan yang diarahkan pada ketercapaian tujuan guna mewujudkan tujuan pendidikan yang dikehendaki, tidak terlepas dari kontribusi elemen yang ada di masyarakat. Adapun elemen yang dimaksud antara lain; pertama, keluarga , sebagai elemen pertama yang mempunyai posisi urgen dalam melakukan proses pendidikan. .kedua, sekolah, elemen ini merupakan kelanjutan dari proses pendidikan di keluarga, dilingkungan ini anak di didik dan ditempat berbagai macam kecerdasan (afektif, kognitif, psikomotor) oleh para tenaga pendidik. Dalam proses ini anak dapat dimonitoring pihak orangtua dan pendidik agar perkembangan karakternya tetap sinergis dengan tujuan pendidikan. Ketiga, masyarakat. Sebagai wadah yang kompleks dan universal. Elemen masyarakat merupakan comunitas seluruh anggota masyarakat yang didalamnya generasi penerus dengan jangkauan adaptasi dan pola interaksi dengan baik dengan seluruh komponeaan masyarakat, melalui karakter yang terbentuk didalam keluarga dan sekolah.

Dalam perspektif psikologi, sebagaimana mengutip pendapatnya langeveld, sebagaimana yang dikutip juga oleh abu Ahmadi, menyatakan bahwa perkembangan anak itu dipengaruhi oleh alam lingkungannya. ${ }^{14}$ Dan meminjam istilah Abu Ahmadi bahwa yang demikian itu, menunjukkan keharusan adanya folkways yang harus terbentuk yaitu kebiasaan harian yang menggambarkan berbagai pola tingkah laku dalam berinteraksi yang baik. ${ }^{15}$

\footnotetext{
${ }^{13}$ Dharma Kesuma, dkk., "Pendidikan Karakter Kajian Teori”..., hal. 10

${ }^{14} \mathrm{Abu}$ Ahmadi dan Widodo supriyono, psikologi belajar, Jakarta; rineka cipta, 2004; 47

${ }^{15}$ Ahmadi,Abu. Sosiologi Pendidikan. Jakarta Rineka Cipta 2007:64
} 


\section{Pendidikan Karakter di Madrasah Ibtidaiyah}

Dalam peta dunia pendidikan di Indonesia, Madrasah memang bukan merupakan produk asli Nusantara. Sebagaimana ditunjukkan oleh kata "Madrasah" itu sendirii, ia berasal dari bahasa Arab yang secara harfiah berarti "sekolah".

Madrasah merupakan isim makan dari "darosa" yang berarti tempat untuk belajar. Istilah madrasah kini telah menyatu dengan istilah ssekolah atau perpendidikan (terutama perpendidikan islam). ${ }^{16} \mathrm{Akan}$ tetapi, menurut karl A. Stendreeng, istilah madrasah dan sekolah dibedakan karena keduanya mempunyai ciri yang berbeda.

Madrasah sebagai lembaga pendidikan merupakan wadah yang benarbenar memenuhi elemen-elemen institusi yang tidak terjadi pada lembagalembaga pendidikan lain. Tugas yang diemban oleh madrasah setidak-tidaknya mencerminkan sebagai lembaga pendidikan Islam yang lain. Menurut AnNahlawi, tugas lembaga madrasah sebagai lembaga pendidikan Islam adalah

1. Merealisasikan pendidikan Islam yang didasarkan pada prinsip pikir,aqidah dan Tasyri' yang diarahkan untuk mencapai tujuan pendidikan bentuk dan realisasi itu ialah agar peserta didik beribadah, mentauhidkan Allah Swt, tunduk dan patuh atas perintahnya, serta syariatnya.

2. Memelihara fitrah peserta didik sebagai insan yang mulia agar ia tidak menyimpang dari tujuan Allah yang telah menciptakan. Oleh karena itu, dasar operasionalisasi pendidikan harus dijiwai oleh fitrah manusiawi, sehingga menghindari adanya penyimpangan.

3. Memberikan kepada peserta didik dengan seperangkat peradaban dan kebudayaan Islam, dengan cara mengintegrasikan antara ilmu alam, ilmu social, ilmu eksakta dengan landasan ilmu agama sehingga peserta didik mampu melibatkan dirinya pada perkembangan IPTEK.

\footnotetext{
${ }^{16}$ poewadaminta WJS, kamus umum Bahasa Indonesia, Jakarta; depdikbud, P3B, balai pustaka, 1982, hal. 618
} 
4. Membersihkan pikiran dan jiwa dari pengaruh emosi karena pengaruh globalisasi, madrasah berperan sebagai benteng yang menjaga kebesihan dan keselamatan fitrah manusia.

5. Memberikan wawasan nilai dan moral, serta peradaban manusia yang membawa hasanah perkembangan berfikir peserta didik.

6. Menciptakan suasana kesatuan dan kesamaan antar peserta didik.

7. Tugas mengkordinasi dan membenahi kegiatan pendidikan

8. Menyempurnakan tugas-tugas lembaga pendidikan keluarga, masjid dan pesantren. ${ }^{17}$

Madrasah Ibtidaiyah sebagai suatu lembaga pendidikan dasar Islam yang lebih modern, yang memadukan antara pendidikan pesantren dan sekolah, yang materinya mengintegrasikan agama dan pengetahuan umum. Madrasah sebagai lembaga pendidikan Islam berfungsi menghubungkan sistem lama dan sistem baru dengan jalan mempertahankan nilai-nilai lama yang masih baik dan dapat dipertahankan dan mengambil sesuatu yang baru dalam ilmu, teknologi, dan ekonomi yang bermanfaat bagi kehidupan umat Islam, sedangkan isi kurikulum madrasah pada umumnya sama dengan pendidikan di pesantren ditambah dengan ilmu-ilmu umum. ${ }^{18}$

Misi jenjang pendidikan dasar adalah berupaya menggali dan mengembangkan seluruh potensi dan dimensi baik personal, agama, susila dan sosial yang dimiliki peserta didik. Melalui usaha ini memungkinkan setiap peserta didik, tanpa kecuali, dapat mendorong tumbuh nilai-nilai kejujuran, keadilan, kasih sayang, toleransi, keindahan, dan tanggung jawab dalam pemahaman nilai sesuai tingkat perkembangan dan kemampuan mereka. Madrasah ibtidaiyah merupakan salah satu jenjang pengembangan potensi dasar yang dimiliki anak. Keberhasilan dalam membimbing peserta didik dalam konflik kepribadian pada usia pendidikan dasar akan sangat menentukan interaksi kehidupan bermasyarakat pada saat beranjak dewasa. Inilah yang menjadi tugas penting bagi orang tua, pendidik, dan masyarakat di sekitar lingkungan peserta didik itu tinggal.

\footnotetext{
${ }^{17}$ (Tim Depag RI, Agama Islam, Jakarta: P3AI-PTU, 1984, Hlm. 12)

${ }^{18}$ Haedar Nashir, “Pendidikan Karakter Berbasis Agama ...” Hlm. 27
} 
Pembentukan karakter adalah bagian integral dari orientasi pendidikan Islam. Proses penerapan pendidikan karakter pada anak usia madrasah ibtidaiyah harus melibatkan aspek perkembangan peserta didik, baik kognitif, afektif, maupun psikomotorik harus menjadi satu keutuhan yang tidak bisa dipisah satu sama lain. Bila tanpa satu dari 3 aspek perkembangan tersebut, maka penerapan pendidikan karakter akan sulit dilaksanakan.Tujuannya adalah membentuk kepribadian seseorang agar berperilaku jujur, baik, bertanggung jawab, menghormati dan menghargai orang lain, adil tidak diskriminatif, pekerja keras, dan karakterkarakter unggul lainnya.

Untuk itulah, pentingnya penerapan pendidikan karakter yang dimulai dari usia kanak-kanak, terutama pada saat usia pendidikan dasar sebagai pijakan melanjutkan pendidikan. Melalui pemberian wewenang penuh pada sekolah yang di dalamnya terdapat unsur pendidik sebagai pelaku utama dalam proses pendidikan, Di sinilah peran pendidik, yang dalam filosofi Jawa disebut digugu lan ditiru (didengar dan dicontoh), dipertaruhkan. Karena pendidik adalah ujung tombak di kelas, yang berhadapan langsung dengan peserta didik. Pendidik adalah model utama untuk peserta didik. Letak keberhasilan pendidikan berkarakter salah satunya ada pada pendidik. Diperlukan pendidik yang berkarakter untuk menghasilkan peserta didik yang berkarakter sesuai dengan tujuan yang diharapkan. Pendidik juga diharapkan dapat lebih mengembangkan dan memberdayakan diri untuk mengembangkan potensi dan dimensi peserta didik agar mampu hidup bermasyarakat.

Kegagalan pendidik dalam menumbuhkan karakter anak didiknya, disebabkan seorang pendidik yang tak mampu memperlihatkan dan menujukkan karakter sebagai seorang yang patut didengar dan diikuti. Sebagai seorang pendidiktidak hanya sekedar menyampaikan materi ajar kepada peserta didik. Namun, yang lebih mendasar dan mutlak adalah bagaimana seorang pendidik dapat menjadi inspirasi dan suri tauladan yang dapat merubah karakter anak didiknya-menjadi manusia yang mengenal potensi dan karakternya sebagai makhluk Tuhan dan sosial. 
Pola pembelajaran juga dapat dilakukan dengan penambahan materi pendidikan karakter, karena pendidikan karakter untuk mengasah kemampuan afektif. Pemberian materi pendidikan karakter bisa dilakukan dengan cerita-cerita keteladanan, seperti cerita Nabi dan pahlawan. Selain itu juga dapat dilakukan dengan contextual learning dengan cara anak diajarkan berakhlak baik dengan langsung dilihatkan pada tindakan-tindakan pendidik.

Tujuan pendidikan nasional sangat memberi perhatian dan menitik beratkan pada penanaman dan pembinaan aspek keimanan dan taqwa. Hal ini sebagai isyarat bahwa "core value" pengembangan pendidikan karakter bangsa bersumber dari kesadaran beragama (religius), artinya input, proses dan output pendidikan harus berasal dan bermuara pada penguatan nilai-nilai ketuhanan yang dilandasi keyakinan dan kesadaran penuh sesuai agama yang diyakininya masingmasing. Hal ini tertuang dalam UUSPN Nomor 20 tahun 2003.

\section{Prinsip Pendidikan Karakter di Madrasah Ibtidaiyah}

Berangkat dari pentingnya nilai pendidikan karakter bagi bangsa ini, maka perlu pedoman untuk mengimplementasikannya agar mendapatkan hasil yang maksimal. Pedoman yang dimaksud adalah prinsip-prinsip pendidikan karakter yang akan menjadi sebuah formulasi kolektif yang saling berkaitan antara satu dengan yang lainnya, sehingga menjadi satu kesatuan yang terintegrasi secara utuh. Secara sederhana, prinsip adalah suatu pernyataan fundamental atau kebenaran umum maupun individual yang dijadikan oleh seseorang atau kelompok sebagai pedoman untuk berpikir atau bertindak. Untuk dapat mengimplementasikan program pendidikan karakter yang efektif, seyogianya memenuhi beberapa prinsip berikut ini:

a. Komunitas Madrasah Ibtidaiyah mengembangkan dan meningkatkan nilai-nilai inti etika dan kinerja sebagai landasan karakter yang baik. Pada usia madrasah ibtidaiyah, penanaman pendidikan karakter bisa diterapkan dengan cara menanamkan keteladanan. Misalnya, pemimpin harus memberi teladan yang baik untuk bawahannya sehingga bawahan akan terajak berbuat baik sesuai dengan perilaku pimpinannya 
b. Madrasah Ibtidaiyah berusaha mendefinisikan "karakter" secara komprehensif, didalamnya mencakup berpikir, merasa, dan melakukan.

c. Madrasah Ibtidaiyah menggunakan pendekatan yang komprehensif, intensif, dan proaktif dalam pengembangan karakter. Pendidikan karakter dimaksudkan untuk membentuk sosok manusia yang kuat dan tidak mudah goyah dalam menghadapi segala permasalahan yang ada. Pendidikan karakter juga menjadi wujud pewarisan kebudayaan karena dengan pendidikan karakter, peserta didik dibentuk untuk tetap berpedoman pada nilai-nilai luhur yang telah ada.

d. Madrasah Ibtidaiyah menciptakan sebuah komunitas yang memiliki kepedulian yang tinggi. lingkungan sekolah harus mendukung adanya pengembangan pendidikan karakter dengan menciptakan situasi dan lingkungan belajar yang sesuai dan dapat dijadikan model pembelajaran peserta didik. Pembelajaran lebih ditekankan pada cara belajar peserta didik aktif yang lebih efektif dalam mengembangkan kemampuan dasar peserta didik

e. Madrasah Ibtidaiyah menyediakan kesempatan yang luas bagi para peserta didik untuk melakukan berbagai tindakan moral.pendidikan dasar harus memfasilitasi peserta didik untuk belajar lebih bebas dan mempunyai pandangan sendiri yang disertai dengan rasa tanggung jawab pribadi yang lebih kuat untuk mencapai tujuan hidup pribadinya atau tujuan bersama sebagai anggota masyarakat.

f. Madrasah Ibtidaiyah menyediakan kurikulum akademik yang bermakna Strategi pengembangan kurikulum pendidikan dasar adalah penekanan pada 4 (empat) pilar pendidikan yang ditetapkan UNESCO, yaitu belajar mengetahui (learning to know), menjadi dirinya sendiri (learning to be), belajar bekerja (learning to do) dan belajar hidup bersama (learning to live together). Pengembangan kurikulum (program belajar) dapat menghargai dan menghormati seluruh peserta didik.mengembangkan karakter mereka, dan berusaha membantu mereka untuk meraih berbagai kesuksesan. 
g. Madrasah Ibtidaiyah mendorong peserta didik untuk memiliki motivasi diri yang kuat.

h. Staf Madrasah Ibtidaiyah adalah komunitas belajar etis yang senantiasa berbagi tanggung jawab.

i. Madrasah Ibtidaiyah mendorong kepemimpinan bersama yang memberikan dukungan penuh terhadap gagasan pendidikan karakter dalam jangka panjang. Pendidikan madrasah ibtidaiyah sebagai salah satu jenjang pendidikan dalam sistem pendidikan nasional yang merupakan fondasi dasar dalam menentukan bagaimana proses pendidikan berikutnya oleh karena itu pendidikan madrasah ibtidaiyah mengutamakan pembentukan watak, karakter, dan kepribadian anak.

j. Madrasah Ibtidaiyah melibatkan keluarga dan masyarakat sebagai mitra dalam upaya pembangunan karakter. Pendidikan dasar merupakan pendidikan lanjutan dari pendidikan keluarga, karena itu, kerja sama antara sekolah dengan keluarga merupakan hal yang sangat penting. Sekolah tidak akan berhasil mengembangkan pendidikan karakter tanpa peran aktif orang tua, begitu juga dengan komunitas masyarakat sejatinya harus sinergis dan harmonis.

k. Secara teratur, Madrasah Ibtidaiyah melakukan assessment terhadap budaya dan iklim sekolah, keberfungsian para staf sebagai pendidik karakter di sekolah, dan sejauh mana peserta didik dapat mewujudkan karakter yang baik dalam kehidupan sehari-hari. ${ }^{19}$

Mendukung prinsip diatas, bahwa pendidikan karakter itu tidak dapat dikembangkan secara cepat dan segera, tetapi harus melewati proses yang panjang, cermat, dan sistematis. Berdasarkan perspektif yang berkembang dalam sejarah pemikiran manusia, pendidikan karakter harus dilakukan berdasarkan tahapan-tahapan perkembangan anak sejak usia dini sampai dewasa. Setidaknya, berdasarkan psikolog .

\footnotetext{
${ }^{19}$ Amirulah Syarbini, Buku Pintar Pendidikan Karakter, (Panduan Lengkap Mendidik Karakter Anak di Sekolah, Madrasah dan Rumah), (Jakarta: as@ @Prima, 2012), hlm. 35-38.
} 
Kohlberg dan ahli pendidikan dasar Marlene Lockheed, terdapat empat tahapan pendidikan karakter yang perlu dilakukan, yaitu:

a. Tahapan pembiasaan, sebagai awal perkembangan karakter anak.

b. Tahap pemahaman dan penalaran terhadap nilai, sikap, perilaku, dan karakter peserta didik.

c. Tahap penerapan berbagai perilaku dan tindakan peserta didik dalam kenyataan sehari-hari.

d. Tahap pemaknaan, yaitu suatu tahap refleksi dari para peserta didik melalui penilaian terhadap seluruh sikap dan perilaku yang telah merekapahami dan lakukan dan bagaimana dampak dan kemanfaatannya dalam kehidupan, baik bagi dirinya maupun orang lain. ${ }^{20}$

Metode Pendidikan Karakter Islami diMadrasah Ibtidaiyah perlu dikembankan padapendidikan karakter agar dapat mencapai pertumbuhan integral, denganmempertimbangkan berbagai macam prinsip penggunaan metode pendidikan yang idealnya memuat nilai-nilai spiritual

Penerapan pendidikan karakter di madrasah ibtidaiyah dilakukan pada ranah pembelajaran (kegiatan pembelajaran), pengembangan budaya sekolah dan pusat kegiatan belajar, kegiatan ko-kurikuler dan kegiatan ekstrakurikuler, serta kegiatan keseharian di rumah dan di masyarakat.

${ }^{20}$ Amirullah Syarbni, “Buku Pintar Pendidikan Karakter ... “ hlm. 42 


\section{PENUTUP}

Pendidikan karakter sangat penting diterapkan demi mengembalikan karakter bangsa Indonesia yang sudah mulai luntur. Dengan dilaksanakannya pendidikan karakter di madrasah ibtidaiyah, diharapkan dapat menjadi solusi atas masalahmasalah sosial yang terjadi di masyarakat. 


\section{DAFTAR PUSTAKA}

Tim penyusun. 2010. Bahan Pelatihan Penguatan Metodologi Pembelajaran Berdasarkan Nilai-Nilai Budaya Untuk Membentuk daya Saing Dan karakter Bangsa : Pengembangan Pendidikan Budaya dan Karakter bangsa. Jakarta : Pusat kurikulum Badan Penelitian Dan Pengembangan Kementerian Pendidikan Nasional.

Tim Penyusun. 2011. Pedoman Pelaksanaan pendidikan Karakter :berdasarkan pengalaman di satuan pendidikan rintisan. Jakarta : Puskurbuk Badan Penelitian Dan Pengembangan Kementerian Pendidikan Nasional.

Tim Penyusun. 2010. Rencana Aksi Nasional (RAN) Pendidikan Karakter Kementerian Pendidikan Nasional 2010-2014 (Online),

http://pendikar.dikti.go.id/gdp/wp-content/uploads/NASKAH-RAN

KEMENDIKNAS-REV-2.pdf,diakses 1 mei 2011dikutip dari mimifdatanjunganom.blogspot.com

Latif Abdul. 2007. Pendidikan Berbasis Nilai Kemasyarakatan,Bandung:Refika Aditama.

Muslich Mansur. 2011. Pendidikan Karakter: Menjawab Tantangan Krisis Multidimensional. Jakarta: Bumi Aksara.

Nata, Abudin. 2003.Manajemen Pendidikan :Mengatasi Kelemahan Pendidikan Islam di Indonesia. Jakarta: Prenada Media.

Robert L. Shannon,Battle. 1978Gagasan Baru dalam Pendidikan, Terj. Sams S. Hutabarat, Jakarta: Mutiara.

Abdul Aziz. Hamka. 2011.Pendidikan Karakter Berpusat Pada Hati. Jakarta: AlMawardi Prima. 
The Random House Dictionary of the English Language. 1983. New York: Random House, Inc

Suyanto,Urgensi Pendidikan Karakter. Dikjen mendikdasmen.

Koesoema, Doni. 2010. Pendidikan Karakter ,(Strategi Mendidik Anak Dijaman Global) Jakarta, Grafindo.

Siregar,Maragustam. Menjadi Manusia Berkarakter.

G stolz,Paul. 2000. Adversity Quotient.

Kesuma, Dharma. Pendidikan Karakter Kajian Teori.

Ahmadi, Abu.2004. Psikologi Belajar, Jakarta; Rineka Cipta.

Abu, Ahmadi. 2007. Sosiologi Pendidikan. Jakarta Rineka Cipta.

Poewadaminta. 1982. Kamus Umum Bahasa Indonesia, Jakarta:Depdikbud, P3B, Balai Pustaka.

Tim Depag RI. 1984. Agama Islam. Jakarta: P3AI-PTU.

Nashir, Haedar. Pendidikan Karakter Berbasis Agama.

Syarbni, Amirullah. 2012. Buku Pintar Pendidikan Karakter.Panduan Lengkap Mendidik Karakter Anak di Sekolah, Madrasah dan Rumah. Jakarta: as@-Prima. 